\title{
Chemopreventive activity of phenylalanine against damage mutagenic prompted by the acute administration of cyclophosphamide in pregnant and non-pregnant mice using the micronucleus test
}

\author{
Mariana de Oliveira Mauro, ${ }^{1}$ João Renato Pesarini, ${ }^{1}$ Priscila Lumi Ishii, ${ }^{1}$ \\ Ariane Fernanda da Silva, ${ }^{2}$ Rodrigo Juliano Oliveira ${ }^{*, 1,2}$ \\ ${ }^{l}$ Centro de Estudo em Nutrição e Genética Toxicológica, Departamento de Biomedicina e Nutrição, Centro \\ Universitário Filadélfia, Av. Juscelino Kubitschek, 1626, Centro, 86020-000 Londrina-PR, Brasil, \\ ${ }^{2}$ Departamento de Biologia Geral, Centro de Ciências Biológicas, Universidade Estadual de Londrina, \\ Rodovia Celso Garcia Cid, PR 445 Km 380, Campus Universitário, Caixa Postal 6001, 86055-900 \\ Londrina-PR, Brasil.
}

\begin{abstract}
RESUMO: "Atividade quimiopreventiva da fenilalanina contra danos mutagênicos pela administração aguda de ciclofosfamida em ratas grávidas e não grávidas, utilizando o teste do micronúcleo". A presente pesquisa teve por objetivo avaliar a capacidade quimiopreventiva da fenilalanina. Utilizou-se um lote de fêmeas prenhes e não prenhes divididas nos seguintes grupos experimentais: G1, PBS (0,1 mL/kg p.c.); G2, ciclofosfamida ( $35 \mathrm{mg} / \mathrm{kg}$ p.c.-i.p.); G3, fenilalanina (150 mg/kg p.c.-v.o.) e G4, fenilalanina (300 mg/kg p.c.-v.o.) e G5 (150 mg/kg p.c. de fenilalanina e $35 \mathrm{mg} / \mathrm{kg}$ de ciclofosfamida); G6, (300 mg/kg p.c. de fenilalanina e $35 \mathrm{mg} / \mathrm{kg}$ de ciclofosfamida). As coletas de sangue periférico foram realizadas em T0, antes da administração de qualquer substância teste e/ou veículos, e igualmente em T24 e T48, onde as coletas foram realizadas respectivamente 24 e $48 \mathrm{~h}$ após a administração da ciclofosfamida. Em uma análise geral verificou-se que, para o grupo de fêmeas não prenhes, a avaliação da antimutagenicidade demonstrou porcentagens de redução de danos de 57,24\% e 31,64\% para G5 e G6, respectivamente, em T24, e 29,32\% e 24,13\% para G5 e G6, respectivamente, em T48. Nos animais prenhes a antimutagenicidade de $24 \mathrm{~h}$ demonstrou eficiência quimiopreventiva apenas para a menor dose (G5) e as porcentagens de redução de danos foram de 43,25\% em G5 e 18,47\% em G6. No momento T48 as porcentagens de redução de danos foram de $44,67 \%$ e $37,76 \%$ para G5 e G6, respectivamente.
\end{abstract}

Unitermos: Fenilalanina, antigenotóxico, ciclofosfamida, prenhes.

\begin{abstract}
This study aimed to evaluate the quimiopreventive ability of phenylalanine. We used pregnant and non-pregnant female mice divided into the following groups: G1-PBS, $(0.1$ $\mathrm{mL} / \mathrm{kg}$ b.w); G2, cyclophosphamide (35 mg/kg p.c.-i.p.); G3 and G4, phenylalanine (150 and 300 $\mathrm{mg} / \mathrm{kg} \mathrm{b.w} \mathrm{respectively-v.o.)} \mathrm{and} \mathrm{G5} \mathrm{and} \mathrm{G6,} \mathrm{association} \mathrm{between} \mathrm{the} \mathrm{two} \mathrm{doses} \mathrm{of} \mathrm{phenylalanine}$ and cyclophosphamide, respectively. The peripheral blood samples were taken at T0, before the administration of any drug test and / or vehicles, also at T24 and T48 where the collections were made 24 and $48 \mathrm{~h}$ after administration of cyclophosphamide, respectively. A general analysis has found that, for the group of non-pregnant female, the antimutagenic evaluation showed reduction percentages of damage of $57.24 \%$ and $31.64 \%$ for G5 and G6, respectively, at T24, and $29.32 \%$ and $24.13 \%$ for G5 and G6, respectively, at T48. Antimutagenic pregnant animals in the $24 \mathrm{~h}$ quimiopreventive efficiency shown only for the lower dose (G5) and the percentages of reduction were $43.25 \%$ in G5 and G6 at $18.47 \%$. At T48 the harm-reduction percentages were $44.67 \%$ and $37.76 \%$ for G5 and G6, respectively.
\end{abstract}

Keywords: Phenylalanine, antigenotoxic, cyclophosphamide, pregnant.

\section{INTRODUCTION}

Several studies, epidemiologic investigations and in vivo and in vitro experiments, have shown that there is an inversely proportional association between the consumption of fruits and vegetables and the risk of cancer development and others pathologies (Flagg et al., 1995; Weisburger, 1999; Zhang et al., 1999; Weisburger, 2000; Ferrari, 1991; Ferrari \& Torres, 2002).

The main inhibitors agents group of the 
carcinogens is represented by the antioxidants, scavenge free radicals. Beyond these there are the inductors of cellular death, enzymatic inhibitors (inhibitors of the enzymes of the cytochrome P450), inhibitors of the angiogenesis, antagonists of growth factors, hormones and restore agents of damage to DNA (Kleiner, 1997; Keloff et al., 1999).

The antioxidants are substances that, even present in low concentrations, are capable of delaying or inhibiting the rates of oxidation (Maxwell, 1995; Sies, 1999). The most utilized classification for these substances is the one that divides them into two systems: enzymatic, composed by the enzymes produced in the organism and not enzymatic, composed by vitamins and other natural compounds such as flavonoids, licopens and bilirrubins (Sies, 1999) and some essential amino acids.

The antioxidant substances act in three lines of organic defense against the reactive species of oxygen: (I) prevention, that characterizes the protection against formation of aggressive substances; (II) interception of free radicals, which once formed initiates its activities of damage to DNA; (III) when the prevention and the interception were not effective and the sub-products of the free radicals activities are continuously being formed in low amounts and being accumulated in the organism, there is the necessity that they are directed to the excretion by the detoxification enzymes, at the same time that the antioxidant substances modulate the repairing system of the DNA cells that are being attacked (Kong \& Lillehei, 1998; Santos \& Cruz, 2001).

Foods containing antioxidants are one of the main groups of food with functional properties, also known as nutraceuticals or medical food (Ferrari \& Torres, 2002).

The concept of functional food comes from the hypothesis that nutritious diet can control and modulate several organic functions, contributing for the maintenance of the health and reducing the risk of the emergence of pathologies (Borges, 2000).

For a food to be classified as a functional one it must: (I) exercise metabolic or physiological effect which contribute for the physical health and for the reduction of the chronic illnesses development risk, (II) be part of the usual food, (III) have in their composition positive effects obtained through non-toxic quantities that should persist even after the suspension of consumption and (IV) should not be utilized with the design of treat or cure illnesses (Milner, 1999).

The possible effect of amino acid nephrotoxicity and toxicity of the cisplatin was investigated by Kroning et al. (2000). The authors observed that the treatment of lineages of the epithelial renal cells with the amino acid methionine, DL-homocysteine and $n$-acetylcysteine was efficient in the inhibition of the cytotoxicity of cisplatin. The modulation of the amino acid glutamine about the nephrotoxicity and lipid peroxidation prompted by the cisplatin in mice was also evaluated and showed effective
(Mora et al., 2003).

Glutamine is the most abundant amino acid in the human system and recent studies show its importance in many clinical situations. One of the important properties of this amino acid is its critic role in the synthesis of glutathione. The pre-treatment with only a single oral dose of glutamine (300 $\mathrm{mg} / \mathrm{kg}$ p.c.) suppressed significantly the lipid peroxidation, prompted seven days after an injection of cisplatin, beyond maintaining the levels of renal glutathione (Mora et al., 2003).

Taking into account that phenylalanine is also an amino acid of a branched chain and possesses an antioxidant activity, it will be able to be tested as an effective protector of damage to DNA. However, according to Degáspari \& Waszczynsky (2004), flavonoids are formed by the combination of synthesized derivatives of the phenylalanine (via metabolic of the shikimic acid) and acetic acid. Firstly, the phenylalanine is converted into cinnamic acid by the phenylalanine ammonia lyase action, it is an enzyme that links primary metabolisms (via the shikimic acid) and secondary (phenylpropanoid). The cinnamic acid is hydrolyzed into coumaric acid that is converted into 4-coumaroyl-CoA which is condensed to three malonyl-CoA units forming a chalcone (C15), from which all flavonoids are formed (Winkel-Shirley, 2001; Huber \& Rodriguez-Amaya, 2008).

Thus, this fact allows interpretations that the phenylalanine supplementation can be an efficient form of diet in preventing damages in the DNA caused by mutagenic agents. Phenylalanine is an essential amino acid to the functioning of the body. The essential amino acids must be supplied by a healthy diet, because its production in the body is insufficient to metabolic demands. The main natural sources of phenylalanine are protein foods of animal origin such as meat and in general, eggs, dairy products and vegetable origin foods (rice, beans, nuts, soy and wheat), however, the latter contain a small amount of free amino acids. They are also found in fermented foods such as yogurt and miso (soybean paste, traditionally consumed by the Japanese). As a supplement, the phenylalanine is available in two forms: DL-phenylalanine (a racemic mixture of D and L-phenylalanine) or L capsules or tablets (Huber \& Rodriguez-Amaya, 2008).

Another important fact of this preventing capacity is related to the glutathione, which is a tripeptide ( $\gamma$-glutamil-L-cysteinelglycine) capable of capturing antioxidant agents (Campbell, 2000).

Due to these reports, the present research aimed to evaluate the effects of the phenylalanine in the prevention of mutagenic damage, in peripheral blood by the micronucleus essay, induced by the acute administration of cyclophosphamide in pregnant and non-pregnant mice.

\section{MATERIAL AND METHODS}

\section{Chemicals}


For the induction of damage to DNA it was utilized the alkylating agent, by indirect action, cyclophosphamide $\left(\right.$ Fosfaseron $^{\circledR}$ ), in the final concentration of $35.0 \mathrm{mg} / \mathrm{kg}$ body weight (b.w), supplied through intraperitoneal (i.p.), diluted in steril phosphate-buffered solution (PBS), $\mathrm{Ca}^{+}$ and $\mathrm{Mg}^{+2}$ free, $\mathrm{pH}$ 7.4.

As a chemopreventive was utilized the amino acid phenylalanine acquired in the Pharmacy of Manipulation La Formula (Number of record 155936-0) with concentrations of 150 and $300 \mathrm{mg} / \mathrm{kg}$ b.w. The referred amino acid was diluted in PBS.

\section{Animals}

It was utilized Swiss mice (Mus musculus), in reproductive age, with medium weight of $30 \mathrm{~g}$, originating from the Centro de Estudos em Nutrição e Genética Toxicológica (CENUGEN)-Centro Universitário Filadélfia (UniFil). The experiment was conducted in the Biotério de Nutrição Experimental-UniFil. The animals were kept in polypropylene cages, isolated and passed by a minimum period of adaptation corresponding to seven days. The brightness and temperature were controlled; for this it was utilized photoperiod of twelve hours (12 h light: $12 \mathrm{~h}$ of darkness) with temperature maintaining around $22 \pm 2{ }^{\circ} \mathrm{C}$. The food was constituted of pure water and commercial feed, ad libitum. All experiments were performed in accordance with the NIH Principles of Laboratory Animal Care.

\section{Experimental Delineation and techniques of analysis}

The animals were divided in two equal lots and maintained in individual cages. The first lot had forty two non-pregnant mice, divided in six groups $(\mathrm{n}=7)$, which have received the following treatment: G1: Group negative control-PBS $0.1 \mathrm{~mL} / \mathrm{kg}$ of body weight $(b . w)$ by gavage and intraperitoneal (i.p.); G2: Group positive control-PBS 0.1 $\mathrm{mL} / \mathrm{kg}$ (b.w) by gavage and cyclophosphamide $35.0 \mathrm{mg} /$ $\mathrm{kg}$ b.w (i.p.); G3: Group control of the diet 1-phenylalanine $150.0 \mathrm{mg} / \mathrm{kg}$ b.w. by gavage and PBS $0.1 \mathrm{~mL} / \mathrm{kg}$ b.w (i.p.); G4: Group control of the diet 2-phenylalanine $300.0 \mathrm{mg} /$ $\mathrm{kg}$ b.w by gavage and PBS $0.1 \mathrm{~mL} / \mathrm{kg}$ b.w (i.p.); G5: Group associated diet 1-phenylalanine $150.0 \mathrm{mg} / \mathrm{kg} b . w$ by gavage and cyclophosphamide $35.0 \mathrm{mg} / \mathrm{kg}$ b.w (i.p.); G6: Group associated diet 2-phenylalanine $300.0 \mathrm{mg} / \mathrm{kg} b . w$ by gavage and cyclophosphamide $35.0 \mathrm{mg} / \mathrm{kg}$ b.w (i.p.).

For the second group it was done the same delineation. However, the females were pregnant. The phenylalanine was given from the eighth to the twelfth gestational day and the cyclophosphamide in the tenth day of the treatment. A sampling of peripheral blood were done at a moment $\mathrm{T} 0$, in other words, before of the administration of any substance test and/or other. At the moments T24 and T48 the samples of blood were done 24 and $48 \mathrm{~h}$ after administration of the cyclophosphamide, respectively. For the first group it was done the same samples but the females were not pregnant. These females received phenylalanine or other vehicle for two consecutive days. After they received the cyclophosphamid, the samples were collected at $\mathrm{T} 24$ and $\mathrm{T} 48$.

\section{Micronucleus assay in peripheral blood}

For the evaluation of the mutagenicity and the antimutagenicity was utilized the micronucleus assay in peripheral blood described by Hayashi et al. (1990) with modifications. For so, a drop of peripheral blood was deposited in a slide previously prepared with a layer formed for $20.0 \mu \mathrm{L}$ of Acridine Orange $(1.0 \mathrm{mg} / \mathrm{mL})$. The slide was then coverslipped and placed in a freezer $(-20$ ${ }^{\circ} \mathrm{C}$ ) for a minimum of $48 \mathrm{~h}$. The slides were analyzed by fluorescence microscopy, using blue light (488 nm) and an orange filter, with a 100 times objective. A total of two thousands cells/animal were examined, and the data were statistically evaluated by the t-Student test $(p<0.05)$.

The reduction percentage of the damage of the mutagenic agent by the phenylalanine was calculated through an average of the number of cells with damage observed in the agent inductor of the damage (cyclophosphamide) except for the number of cells with damage observed in the treatment of antimutagenicity (phenylalanine + cyclophosphamide) times 100, divided by the number of cells with damage observed in the agent inductor of damage except for the number of cells with damage from the control (PBS).

\section{RESULTS}

In the Table 1 are presented the frequency, average, standard deviation and damage reduction percentage regarding to the essay of the micronucleus in peripheral blood of non-pregnant mice. The statistical analysis indicated that in T0 all groups had similar frequency of micronucleus. The average varied from $3.00 \pm 1.69$ to $4.71 \pm 1.70$. However, at moment T24 it was verified that the cyclophosphamide (G2), mutagenic of indirect action, was efficient in cause damage to DNA and the average increased in 10.7 times regarding to the group control (G1). The evaluation of the mutagenicity of the phenylalanine (G3 and G4) showed differences statistically significant. The smaller dose of phenylalanine (G3-150 $\mathrm{mg} / \mathrm{kg}$ ), presented an increase of 5.43 times and the bigger dose $(\mathrm{G} 4-300 \mathrm{mg} / \mathrm{kg}$ ), presented an increase of 8.94 times, both compared to the negative control group. On the other hand, the evaluation of the antimutagenicity showed damage reduction percentages towards positive control group of $57.24 \%$ and $31.64 \%$ for G5 and G6, respectively. The same statistical analysis, when it was done $48 \mathrm{~h}$ after administration of the drugs and/or vehicles, indicated that the agent inductor of damage in the DNA (G2) promoted development in the frequency of micronucleus of 12.62 
times regarding the group control (G1). The analysis of the mutagenicity indicates that this amino acid has the capacity for increasing the occurrence of micronucleus, in peripheral blood of non-pregnant female mice. The development was 4.34 times for $\mathrm{G} 3(150 \mathrm{mg} / \mathrm{kg})$ and 6.48 times for G4 $(300 \mathrm{mg} / \mathrm{kg})$ when compared to the positive

Table1. Frequency, mean, standard deviation and reduction of damage percentage relating to the micronucleus in peripheral blood from female mice non-pregnant in acute treatment.

\begin{tabular}{|c|c|c|c|c|c|c|c|c|}
\hline \multirow{2}{*}{ Treatment } & \multicolumn{3}{|c|}{ Micronucleus Frequency } & \multicolumn{3}{|c|}{ Mean \pm Standard deviation } & \multicolumn{2}{|c|}{$\% \mathrm{RD}$} \\
\hline & T0 & $\mathrm{T} 24$ & $\mathrm{~T} 48$ & T0 & $\mathrm{T} 24$ & $\mathrm{~T} 48$ & $\mathrm{~T} 24$ & $\mathrm{~T} 48$ \\
\hline Group 1 & 21 & 12 & 15 & $3.00 \pm 1.69$ & $1.71 \pm 0.88$ & $2.14 \pm 0.83$ & - & - \\
\hline Group 2 & 29 & 129 & 189 & $4.14 \pm 2.23^{\mathrm{a}}$ & $18.43 \pm 2.06^{\mathrm{a} *}$ & $27.00 \pm 6.19^{\mathrm{a} *}$ & - & - \\
\hline \multicolumn{9}{|c|}{ Mutagenicity } \\
\hline Group 3 & 30 & 65 & 65 & $4.29 \pm 1.89^{\mathrm{a}}$ & $9.29 \pm 1.80^{\mathrm{a} *}$ & $9.29 \pm 1.98^{a *}$ & - & - \\
\hline Group 4 & 31 & 107 & 97 & $4.43 \pm 1.72^{\mathrm{a}}$ & $15.28 \pm 2.56^{\mathrm{a} *}$ & $13.86 \pm 2.73^{\mathrm{a} *}$ & - & - \\
\hline \multicolumn{9}{|c|}{ Antimutagenicity } \\
\hline Group 5 & 25 & 62 & 138 & $3.57 \pm 2.30 \mathrm{~b}$ & $8.86 \pm 1.46 b^{*}$ & $19.71 \pm 2.93 b^{*}$ & 57.24 & 29.32 \\
\hline Group 6 & 33 & 92 & 147 & $4.71 \pm 1.70 b$ & $13.14 \pm 2.19 b^{*}$ & $21.00 \pm 2.31 b^{*}$ & 31.64 & 24.13 \\
\hline
\end{tabular}

Group 1: Phosphate-buffered solution; Group 2: Cyclophosphamide (35.0 mg/kg, b.w-i.p.); Group 3: Phenylalanine (150.0 mg/ $\mathrm{kg}$, b.w., gavage); Group 4: Phenylalanine (300.0 mg/kg b.w., gavage); Group 5: Cyclophosphamide (35.0 mg/kg, b.w.-i.p.) + Phenylalanine (150.0 mg/kg, b.w., gavage); Group 6: Cyclophosphamide (35.0 mg/kg, b.w.-i.p.) + Phenylalanine (300.0 mg/ $\mathrm{kg}, b . w$., gavage). T0: peripheral blood collect put into practice before drugs administration; T24: peripheral blood collect put into practice $24 \mathrm{~h}$ after the first administration; T48: peripheral blood collect put into practice $48 \mathrm{~h}$ after the first administration.

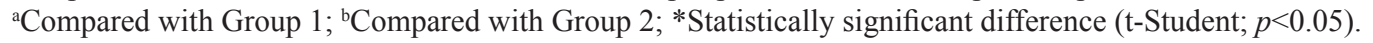

Table 2. Frequency, mean, standard deviation and reduction of damage percentage relating to the micronucleus in peripheral blood from female mice pregnant in acute treatment.

\begin{tabular}{|c|c|c|c|c|c|c|c|c|}
\hline \multirow{2}{*}{ Treatment } & \multicolumn{3}{|c|}{ Micronucleus Frequency } & \multicolumn{3}{|c|}{ Mean \pm Standard deviation } & \multicolumn{2}{|c|}{$\% \mathrm{RD}$} \\
\hline & $\mathrm{T} 0$ & $\mathrm{~T} 24$ & $\mathrm{~T} 48$ & T0 & $\mathrm{T} 24$ & $\mathrm{~T} 48$ & $\mathrm{~T} 24$ & $\mathrm{~T} 48$ \\
\hline Group 1 & 14 & 17 & 9 & $2.00 \pm 1.63$ & $2.43 \pm 1.99$ & $1.29 \pm 0.95$ & - & - \\
\hline Group 2 & 15 & 158 & 266 & $2.14 \pm 1.07^{\mathrm{a}}$ & $22.57 \pm 4.39^{\mathrm{a} *}$ & $38.00 \pm 3.51^{\mathrm{a} *}$ & - & - \\
\hline \multicolumn{9}{|c|}{ Mutagenicity } \\
\hline Group 3 & 22 & 34 & 45 & $3.14 \pm 1.57^{\mathrm{a}}$ & $4.86 \pm 2.27^{\mathrm{a}}$ & $6.43 \pm 2.22^{\mathrm{a} *}$ & - & - \\
\hline Group 4 & 46 & 84 & 69 & $6.57 \pm 1.62 b^{*}$ & $12.00 \pm 1.91^{\mathrm{a} *}$ & $9.86 \pm 1.57^{\mathrm{a} *}$ & - & - \\
\hline \multicolumn{9}{|c|}{ Antimutagenicity } \\
\hline Group 5 & 30 & 97 & 152 & $4.29 \pm 1.50 b^{*}$ & $13.86 \pm 5.24 b^{*}$ & $21.71 \pm 6.42 b^{*}$ & 43.25 & 44.37 \\
\hline Group 6 & 35 & 132 & 169 & $5.00 \pm 1.91 b^{*}$ & $18.85 \pm 1.68 b$ & $24.14 \pm 2.54 b^{*}$ & 18.47 & 37.76 \\
\hline
\end{tabular}

Group 1: Phosphate-buffered solution; Group 2: Cyclophosphamide (35.0 mg/kg, b.w.-i.p.); Group 3: Phenylalanine (150.0 mg/ $\mathrm{kg}$, b.w., gavage); Group 4: Phenylalanine (300.0 mg/kg b.w., gavage); Group 5: Cyclophosphamide (35.0 mg/kg, b.w.-i.p..) + Phenylalanine (150.0 mg/kg, b.w., gavage); Group 6: Cyclophosphamide (35.0 mg/kg, b.w.-i.p..) + Phenylalanine (300.0 mg/ $\mathrm{kg}, b . w$., gavage). T0: peripheral blood collect put into practice before drugs administration; T24: peripheral blood collect put into practice $24 \mathrm{~h}$ after the first administration; T48: peripheral blood collect put into practice $48 \mathrm{~h}$ after the first administration. ${ }^{\mathrm{a} C}$ Compared with Group $1 ;{ }^{\mathrm{b}}$ Compared with Group $2 ; *$ Statistically significant difference (t-Student; $\left.p<0.05\right)$. 
control group. The evaluation of the mutagenicity indicates capacity chemopreventive for both doses and the damage reduction percentage was $29.32 \%$ and $24.13 \%$ for G5 and G6, respectively.

In Table 2 it is found the frequency, average, standard deviation and damage reduction percentage regarding the essay of the micronucleus in peripheral blood of pregnant female mice in acute treatment. The analysis of the T0 moment indicated that the G4, G5 and G6 had micronuclei frequency statically superior to that one observed in the control group (G1). In the evaluation of the T24 moment it was verified that the cyclophosphamide was efficient in causing damages to the DNA. The mutagenicity indicated that only the biggest dose was responsible for the rise of the micronuclei frequency and this was corresponding to 4.94 times more than G1. In the antimutagenicity analysis was observed efficiency chemopreventive in the lesser dose (G5) and the percentages of damage reduction was $43.25 \%$ and $18.47 \%$ to G5 and G6, respectively. At the T48 moment it was verified that the increase of the micronuclei frequency in the mutagenicity tests for both of the doses. However, the antimutagenicity of the same doses was verified and the percentages of damage reduction were $44.37 \%$ and $37.76 \%$ for G5 and G6, respectively.

\section{DISCUSSION}

Regarding the previously reported activities about phenylalanine, this research is seen as a pioneer work in the attempt to demonstrate the chemopreventive capacity of the phenylalanine and go through assumptions regarding the supplementation of cancer prevention and/ or the improvement of the life quality for the patients in chemotherapy.

In accordance with these descriptions, the considered experimental delineation possess five doses of phenylalanine associated with a cyclophosphamide dose, which was administered during the period of treatment. The choice of this experimental delineation was done so that the organism already had possessed increased concentrations of phenylalanine before, during and after the exposition to the chemoterapic, and thus, in case it exerted an antioxidant effect, it could act previously in the three presented lines of organic defense. The analysis of the results demonstrated that at the beginning of the experiments the group of nonpregnant female had presented frequency of similar basal micronuclei among the different groups. The values shown by groups five and six in Table 2 are too close to the ones shown in Table 1 where they were not mutagenic, thus, although statistics points out a difference, one may wonder about the biological value of the data.

Whereas in the pregnant females lot (G4, G5 and G6 groups) had an increased basal frequency despite not having any symptom of any pathology that could lead to the increase of damages in the DNA. During the evaluation of the mutagenicity of the phenylalanine, it was observed that it presented mutagenic activity in the two doses tested for the group of non-pregnant females and only for higher dose in the group of pregnant females. This fact can suggest that the pregnant female possesses a metabolism with bigger consumption of phenylalanine in such way it does not have a large agglomerate of this amino acid that can cause damage to the organism as it seems to have occurred in the group of non-pregnant females.

The hyperphenyl-alaninemia is innate errors of the metabolism, of recessive autosomic inheritance, whose primary disorder locates in the conversion of the phenylalanine amino acid in tyrosine by deficiency of the hepatic enzyme phenylalanine-hydroxylase. In consequence of this, occurs an increase of the phenylalanine concentration and its sub-products in the blood and urine (phenylpyruvate, phenylacetate, phenylactate and phenylacetylglutamine), with reduced formation of tyrosine. Serious cerebral damage are caused by the rise of the plasmatic concentration of phenylalanine in the organism, such as the competitive inhibition of the transport of the other necessary amino acids to the protein synthesis, weak formation or stabilization of polyribossome, reduced synthesis and increased degradation of myelin, as well as inadequate formation of norepinehrine and serotonin (Longo, 2002; Figueiró-Filho et al., 2004), beyond these facts can still occur the inadequate formation of enzyme involved in the detoxification of the organism, as it is the case of enzymes from glutathione, enzyme from Phase II.

Glutathione, enzyme from Phase II, involved in the detoxification processes, constitutes an important system of endogenous protection of the cells against the damage provoked by toxic substances and oxidant substances produced by its metabolism. Glutathione is presented in raised concentrations in the mammal cells and all vertebrates, under reduced form (GSH), next to inferior amounts of oxidated form (GSSG) (Wilhelm-Filho et al., 2000). A fall in the levels of glutathione, in its reduced form $\mathrm{GSH}$, from 20 to $30 \%$ can harm the cellular defenses against the toxic action of the oxidant radicals leading to the cellular damage and the death (Heffner \& Repine, 1989). According to Matsubara (1997), under conditions of excess of oxidant agents and/or deficiency of the protective system, there will be disequilibrium between the GSH consumption and the GSSG production, what characterizes equally stress oxidative. Thus, the magnitude of stress oxidative can be monitored by GSSG/GSH ratio.

In this way, this fact can help understanding why the completion of this amino acid is capable to provoke mutagenic activity. On the other hand, the same enteral diet, when associated a chemoterapic agent, is capable to reduce the mutagenic damage caused as collateral effect. It is important to say that the reduction of this effect is synonymous of improvement of quality of life of a patient in chemotherapy.

A general analysis of the antimutagenicity 
indicates a chemopreventive activity of the phenylalanine for the two groups. However, it shows more effective for the pregnant females. Another fact that calls attention is that the completion of the lower dose demonstrates better antimutagenic activity and it is evaluated by a great percentage of damage reduction. It is still necessary to observe that it did not have a correlation dose-response for the tested doses.

In such a way, it is observed that the completion of lower doses would not induce a temporary hyperphenylalaninemia and thus would have minor mutagenic effects as a result of the completion. Even with completion enterals of low doses this amino acid would be capable to exert its antioxidant and antimutagenic activity.

Confronting the presented results it is verified that there is a necessity of new studies on the compliment of enterals diets by phenylalanine for the prevention of damages to DNA, as well for the improvement of the quality of life to patients in chemotherapy, once that, despite this amino acid is capable to reduce the actual damage for the chemoterapic in study, it is also capable to cause the increase of the frequency of micronuclei. Thus, new studies are suggested to test lower doses of phenylalanine to prove if it will continue provoking the induction of micronuclei or if the same one will only present chemopreventive capacity.

\section{ACKNOWLEDGEMENTS}

This study has been supported by Pró-reitoria de Pesquisa e Pós-graduação, Centro Universitário Filadélfia (UniFil). It is also necessary to thank Dra. P. Pesarini and J. R. Pesarini for English language editing of the manuscript.

\section{REFERENCES}

Borges VC 2000. Alimentos funcionais: prebióticos, probióticos, fitoquímicos e simbióticos. In: Waitzberg DL (org.). Nutrição oral, enteral e parenteral na prática clínica. 3. ed. São Paulo: Atheneu, p. 1495-1509.

Campbell MK 2000. Bioquímica. Porto Alegre: Artmed.

Degáspari CH, Waszczynskyj N 2004. Propriedades antioxidantes de compostos fenólicos. Visão Acad 5: 3-40.

Ferrari I 1991. Teste do micronúcleo em cultura temporária de linfócitos. In: Rabello-Gay MN, Rodrigues MALR, Monteleone-Neto R (Org.). Mutagênese, Teratogênese e Carcinogênese: métodos e critérios de avaliação. Ribeirão Preto: Sociedade Brasileira de Genética/Revista Brasileira, p. 107-112.

Ferrari CKB, Torres EAFS 2002. New dietetic compounds with anticarcinogenic properties. Rev Bras Cancerol 48: 375382.

Figueiró-Filho EA, Lopes AHA, Senefonte FRA, Souza-Júnior VG, Botelho CA, Duarte G 2004. Fenilcetonúria materna: relato de caso. Rev Bras Ginecol Obstet 26: 813-817.

Flagg EW, Coates RJ, Greenberg RS 1995. Epidemiologic studies of antioxidants and cancer in humans. J Am Coll Nutr 14: 419-427.
Hayashi M, Morita T, Kodama Y, Sofuni T, Ishidate-Jr M 1990. The micronucleus assay with mouse peripheral blood reticulocytes using acrideine arange-coated slides. Mutat Res 245: 245-249.

Heffner JE, Repine JE 1989. Pulmonary strategies of antioxidant defense. Am Rev Respir Dis 140: 531-554.

Huber LS, Rodriguez-Amaya DB 2008. Flavonóis e flavonas: fontes brasileiras e fatores que influenciam a composição em alimentos. Alim Nutr 19: 97-68

Kelloff GJ, Crowell JA, Steele VE, Lubet RA, Boone CW, Malone WA, Haw ET, Lieberman Lawrence JA, Kopelovich L, Ali T, Viner JL, Sigman CC 1999. Progress in cancer chemoprevention. Ann N Y Acad Sci 889: 1-13.

Kleiner SM 1997. Defense plants: foods that fight disease. http:// www.physsportsmed.com. Acesso em 28 de setembro 1998.

Kong Q, Lillehei KO 1998. Antioxidant inhibitors for cancer therapy. Med Hypotheses 51: 405-409.

Kroning R, Lichtenstein AK, Nagami GT 2000. Sulfur-containing amino acids decrease cisplatin cytotoxicity and uptake in renal tubule epithelial cell lines. Cancer Chemoth Pharm 45: 43-49.

Longo N 2002. Distúrbios hereditários do metabolismo e do armazenamento de aminoácidos. In: Braunwald E, Fauci AS, Kasper DL, Hauser SL, Longo DL, Jameson JL (org.). Harrison Medicina Interna. 15. ed. Rio de Janeiro: MCGraw Hill, p. 2450-2451.

Matsubara LS 1997. Radicais livres: conceitos, doenças relacionadas, sistema de defesa e estresse oxidativo. Rev Assoc Med Bras 43: 61-68.

Maxwell SRJ 1995. Prospects for the use antioxidant therapies. Drugs 49: 345-61.

Milner JA 1999. Functional foods and health promotion. $J$ Nutr 129: 1395-1397.

Mora LO, Antunes LMG, Francescato HDC, Bianchi MLP 2003. The effects of oral glutamine on cisplatin-induced lipid peroxidation and nephrotoxicity in rats. Pharmacol Res 47: 517-522.

Santos HS, Cruz WMS 2001. The antioxidant vitamin nutritional therapy and the chemotherapy treatment in oncology. Rev Bras Cancerol 47: 303-308.

Sies H 1999. Strategies of antioxidant defense. Eur J Biochem 215: 213-219.

Weisburger JH 1999. Mechanisms of action of antioxidants as exemplified in vegetables, tomatoes and tea. Food Chem Toxicol 37: 943-948.

Weisburger JH 2000. Eat to live, not live to eat. Nutrition 16: 767-773.

Wilhelm-Filho D, Torres, MA, Marconi, JL, Fraga, CG, Boveris, A 2000. Comparative antioxidant defences in vertebratesemphasis on fish and mammals. Comp Biochem Phys 7: 33-45.

Winkel-Shirley B 2001. Flavonoid biosynthesis. A colorful model for genetics, biochemistry, cell biology, and biotechnology. Plant Physiol 126: 485-493.

Zhang S, Hunter DJ, Forman MR, Rosner BA, Speizer FE, Colditz GA, Manson JE, Hankison SE, Willett WC 1999. Dietary carotenoids and vitamins A, C, and E and risk of breast cancer. J Natl Cancer I 91: 547-556. 